\title{
The Bitches of Barcelona Street
}

My Grandma Louisa always smelled of sherry wine. Whenever she minded us kids while Mama did "day's work" for one of the white families in the neighborhood, Grandma would herd us all out to her favorite spot in the backyard, and, with a heavy groan, plunk her bulk down in the used-to-be-green metal lawn chair that had been part of the landscape back there for as long as I can remember. We laughed when the paint-flaked old chair let out a groan almost as loud as Grandma did when she sat in it. Then we began our mad scramble for the most coveted seats: on her ample lap where we could rest our heads on the soft cushion of her equally ample bosom. When two of us had each claimed a knee, the others found a spot in the grass still warm from the day's heat.

Whether standing or sitting, we began at once with our favorite pastime: unplaiting and combing Grandma's two long, thick braids that age had turned first white then yellow. We'd drape the loosened hair over her shoulders like a shawl and "style" it, which she let us do until her head was too sore to take any more of our grooming. By then, her hair stuck up and out like chickens had been plucking in it.

Grandma Louisa always sang to us, most often tunes that were popular in her day. She'd croon "Red Sails in the Sunset," "I'll Be Seeing You," and other love ballads. We were a rapt audience. While she sang, she sipped sherry from a fifth bottle stashed beneath her chair, and sometimes I got the feeling that she wasn't even aware she had an audience, rapt or not.

Often in the middle of a song her voice would slowly fade, and her entire body would sag. She appeared to be spiraling down like my brother's spinning top, then her head slumped to her chest and the singing stopped. The forgotten bottle dangled from her hand, then dropped with a soft thud on the grass like a period at the end of a sentence. The quiet that hung upon the night then seemed to amplify the usual nocturnal chirr of crickets, cicadas, and whippoorwills. We kids looked at each other, but no one spoke. What was there to say? We all knew Grandma was drunk. But even though we 
were kids we could tell, somehow, that her kind of drunk was not the same as our daddy's kind. Drinking made our daddy mean; it made our grandma sad. In fact, there was a perpetual look of sadness in her eyes that nothing seemed to erase. Neither the laughter when she set out to amuse us nor the rare smile she allowed to rearrange the lines on her face ever seemed to make it all the way to her eyes.

After a minute or two, Grandma Louisa came back from wherever it was she'd gone. Most of the time, on her return she resumed her singing as if nothing had happened, dipping into her extensive repertoire of fun songs and bouncing us on her knees to uproarious rhythms. In no time, she'd have us clapping and singing, belting out fractured lyrics we couldn't pronounce and to whose meaning we had not a clue. We loved it; in fact, the stranger-sounding the words, the more we liked the song. Well into her bottle, Grandma led us in a rousing chorus of "McNamara's Band" and other songs that relied less heavily on our understanding of the lyrics than on our enjoyment of their rhythms and sounds. One such favorite was "Jambalaya," whose refrain was perfect for really punching out its already stressed syllables:

"Jum-bu-lie, craw-fish-pie, fee-lay-gum-bo...!"

Grandma didn't always come back, though, in such a fun mode. Often it seemed to require great effort for her to lift her head. We knew then the day's fun was over. I always got the feeling she'd left us to go off and talk to God. Her "returns" were usually accompanied by the lament, "Lord, I borned that child."

We all knew the subject of her anguish was our father, but it was years before I understood the real significance of that simple prayer: Not only was my grandma admitting guilt for bringing my daddy into the world, but this good and pious woman was also apologizing to God for the sins of her son. Her life had been nothing more than one big atonement for his sins.

"Miss Louisa," as Mama called her, always tried to do her best by her daughter-in-law but, in spite of her efforts, the two women did not always see eye to eye. One sticking point between them was Grandma's cooking. When she minded us while Mama worked, she often tried to help by cooking the evening meal. Mama would come home, look into the pot, and shake her head in frustration. 
"Miss Louisa, how many times I gotta ask you not to do this?" Mama fussed. "This" meant that Grandma had made another one of what Mama called her "stretch" meals by adding too much water to the pot. Grandma "stretched" gravies, soups, gumbos and anything else that required broth or any other liquid.

"God!" Mama would say, shaking her head in frustration. "You just seem to have a knack for ruining perfectly good food!" With a look of wonderment on her face and shaking her head again, she mumbled, "I just don't know...." Mama left the words circling in the air like smoke rings as she turned to walk out of the kitchen.

"Now, Helen, you know I was only trying to make..." Grandma began her usual response, but Mama cut her off.

"That's just the problem, Miss Louisa!" Mama turned back and yelled, "You're always trying to 'make enough to go around,' or 'make ends meet,' or 'make'... some damn thing! Well, what you need to do is make that no-good son of yours get a damn job and make some money so we can buy enough food to make a decent meal!" Mama stopped, caught her breath and heaved a cathartic sigh, but seeing Grandma's hangdog look, she became contrite.

"Look, Miss Louisa," Mama said. "I know you're just trying to help... and I appreciate it. Lord knows it's not your fault, so.... Let's just forget about it, okay?" Both knew the real cause of their being at dagger's point was not each other, so, once again, they formed a truce-until the next time. Grandma admitted that she didn't always get things right, and Mama accepted her efforts as well-meaning. Both women knew that her attempts to help were the old lady's way of trying to make up for the bastard her son was.

And, you know? My daddy really was a bastard-not by birth but by temperament. Contrarily, his mama, everyone said, was a saint; yet, in spite of their very different natures there was a strong physical resemblance between mother and son: both were olive-complexioned with high cheekbones, and both had thick, white hair; they say my daddy's hair had turned white when he was still in his twenties. More significantly, they shared a love for those "demon spirits," though Daddy's choice of drink was nothing as tame as Grandma's sherry.

Though any alcohol would do, mostly he drank a cheap whiskey he called "shinny." I think the name was a corruption of the 
brand name Schenley. When he was in the bottle, the resemblance between mother and son ended. The more Daddy drank the meaner he got. It was the "shinny," Grandma insisted; it made him crazy. But I'm sure she knew as we all did that it was his drinking that made him crazy, not his drink.

The slam of the door at night had a reflex effect on all of us. Early or late, we kids came awake, ears alert for sounds from the adjoining room. We waited. The next few minutes would determine the direction of the rest of our night. Was Daddy stumbling drunk or sloppy drunk? No one made a sound as we listened for his heavy body to fall into bed in the other room. When he was stumbling drunk, he sometimes missed the bed completely. We listened, hoping that's what would happen because when he woke up the next morning and picked himself up off the floor, the consequences were unpleasant, but not as bad as when he was sloppy drunk. He'd drag himself over and flop across the bed, so angry he'd cuss up a storm, accusing us of having tossed him on the floor the night before.

But if, a few minutes after Daddy hit the bed, Mama quietly tiptoed into our room and crept into bed with one of us, we knew he was sloppy drunk, which meant there would be no sleep and bad things were likely to happen that night. The ugliness usually began when Daddy came out of his fog and realized Mama was missing from their bed. He'd start calling her name, softly at first, even sensually: "Helen-n-n-n." His coaxing voice was the only sound in the house. "Helen-n-n-n." Everything outside those two rooms stopped as reality. The world had simply gone out for us as if Daddy had reached out and flicked it off like a light switch. In the darkness, the only sound was his drunken voice, then nothing. After each period of silence, we waited, hoping he had finally gone to sleep. The darkness remained constant, but the disembodied voice grew louder, more insistent.

"Helen!" the name exploded in the otherwise quiet night, soon followed by a string of obscenities liberally punctuated with "bitch!" This vulgar tirade usually went on for what seemed like forever, or until Daddy finally fell asleep.

Mama joked-afterwards - that he had called her "bitch" so often she began to think it was her name. "But," she mused aloud, "there was nothing even slightly amusing about any of it at the time." 
Daddy's frequent binges didn't always end in such relative peace. Unfortunately most nights they ended in drunken rages that touched us all in one way or another. His favorite tool of terror was always a knife-which he'd brandish while chasing us out of the house-so knives became anathema to Mama. Whenever Daddy fell into one of his alcoholic comas, she went straight for his pockets. When she found what she was looking for, she would hand it over to one of us to bury in the backyard. Surprisingly, Daddy never suspected that she was the reason his knives kept coming up missing, or, if he did, he couldn't prove it. But no matter how many she relieved him of, he somehow always managed to get another. The wonder of it was how he could afford to keep replacing them when most of the time he couldn't buy a loaf of bread. But the darndest thing was that Mama managed, as usual, to squeeze a bit of humor out of even that. She said that if anyone ever had cause to dig in our backyard, they'd uncover enough knives to fill a small museum.

My daddy was a bastard, all right; no doubt about that. We witnessed his dark side too often to deny it. But, strangely enough, there were the rare times we got a glimpse of his other side-who he once was. Ironically, when he was sober he was one of the most charming men you could meet: funny, intelligent, even romantic according to Mama. It was her thinking that that was usually the case with most drunks. "When they're not being bastards," she'd say, "they could charm the sweetnin' out of gingerbread." More out of childish anger and frustration than any expectation of an answer, I decided to ask her. Without soundin' too sassy.

"Then, if he's so charming, why is he so mean to you-and to us? Tell me that, Mama!" Oh, she gave me an answer all right, but I couldn't begin to understand it.

"Because," she said, "like most drunks, he thinks way too much and feels way too much, and when the bad feelings become more than he can take in and he's filled up to the brim, I guess he just... explodes."

"But he always takes it out on us? Why? We ain't done nothing."

"Well," she said, "who else? We right here, Diane, so where else you think all the you-know-what's gon' fall if not on our heads?"

"But that ain't fair!" I protested. 
"No, it ain't. Neither is a lotta things in life. But what you gon' do?"

I had no idea, and I figured Mama didn't either. She went on, though, I suppose in an attempt to recapture for me-or herself?another time when Daddy was different.

"Your daddy was a good man, Diane, once upon a time," she said. "Oh, I don't mean he was no saint or nothin', but just a ordinary, good man."

"So what happened to him?" I wanted to know.

"Well, I think poverty's what happened, Diane. Poverty's what drove your daddy to drink, and drink's what keeps him in poverty. You see, people like him with a mean streak wide as a house, and 'specially people who got problems already, ought'n to go nowhere near a damn bottle!"

That I could understand, and she sounded so intense that I swallowed the words I had intended to say. Sure, I knew my daddy had charm and talent, and just as we fell victim to his meanness, we also fell victim to his charm. He not only played the violin but, like his mama, he had a beautiful voice, and during the rare good times, he would croon to Mama, a special twinkle in his eyes for her and conspiratorial winks for us kids. Some nights were filled with the beautiful tunes and lyrics of "Love is Like a Melody," "Alice Blue Gown," "I Cover the Waterfront," "Melancholy Baby," and others before our time but that obviously had significance to both of them given their behavior. I guess maybe Mama did know her husband, and during those pleasant times it was easy to see why she fell in love with him.

He'd sometimes switch to his comedic mode for us kids, singing in a rousing basso, "Caldonia! What make yo' big head so hard!" punctuating the last word with a resounding sтомp! on the linoleum floor, and we knew exactly when to join in. Then we'd fall all over ourselves laughing. Looking back, I realize our laughter was often over-the-top and even bordered on hysterical because we knew those moments were rare and short-lived. Too young to have ever heard of the idea that "fate works most for woe," we had, in spite of our youth, experienced the concept, and dared not trust the moment.

Grandma Louisa slept on a rollaway in a corner of the living room. We kids slept on used cots and mismatched beds, sometimes taking 
turns sleeping on pallets on the floor in one of the two bedrooms in our four-room house. We didn't mind being all squeezed into one small room; in fact, we found some small degree of solace-even safety, I guess, being in such proximity.

One summer somebody gave us a puppy. We made a bed for it from a cardboard box lined with old rags and placed it in the corner of the back porch. One night-morning actually-just before daybreak the puppy, restless and unsettled, began to whimper and whine, prompting a whiskey voice to bellow from the darkness inside. In a vulgar intrusion on the peaceful night, which I'm sure everybody on Barcelona Street must have heard, Daddy began to yell and curse.

"Somebody get rid of that goddamn dog, y'hear?" he ordered. And since the puppy had been given to Junior, he knew it was his responsibility. He eased out of bed and went out to the porch and picked up the trembling bundle of fluff. Cradling it in his arms, he whispered, "Shhh! Hush up, y'hear? Shhh!" He pleaded frantically to the puppy, who must have detected the desperation in our brother's voice because the animal soon became quiet-but not before the bellowing started up again.

"I told y'all to get that fuckin' dog the hell away from here, didn't I? You don't, I'm gonna come out there and ring his goddamn neck like a fuckin' chicken!"

The rest of us, all trying to peek through the already raggedy screen door at the same time, stretched the rusty screen to its limits as we watched Junior pad barefoot across the back porch, boards creaking with every step he took. We all knew, as I'm sure Junior did, the noise of the boards didn't matter now; the dragon was no longer sleeping.

"I ain't scared of him," Junior consoled the puppy... and us. “Don't you be scared, either. I ain't gonna let him hurt...nobody, y' hear?" He crept off the end of the porch and around to the front of the house, and we all turned and tiptoed to the front window.

The street lamps were still on and spread their amber blanket over the sleeping houses. Strong breezes from the nearby bay roughly tickled the chinaberry trees, setting up a whicker-whicker among the leaves and creating dappled shadow-monsters on the sidewalk and street. Our eyes followed Junior, half naked and hugging the puppy to his bare chest, as he edged along Barcelona Street until he was 
beyond our view. We stayed at the window and watched the day begin to break over rooftops and behind chimneys off in the near distance, and we waited.

Junior told us years later some of what he had felt that night. Of the many emotions swirling around in his head, he said that anger, guilt, and frustration were the dominant three, creating a whirlpool with him at its vortex. His anger was directed at Daddy for his meanness and violence, but the guilt, Junior said, was his own. $\mathrm{He}$ felt that as the oldest it was his job to protect the family from Daddy's wrath, which he had failed to do. His frustration, he said, was the result of not knowing just how to do that.

On the corner that still-dark, early morning, he told us, as he stared up at the steeple of St. Joseph's with the puppy in his arms, he agonized over his failure. Then, he said, his mind turned to Father Joe, the one priest in the parish who was more of a father to most of the boys than their own fathers. Junior said that of the many things he remembered that Father Joe had taught his boys, what flashed across his mind that early morning was the priest's reminder that we must "never question God's prerogatives." He had also told them-as well as the girls-that "God works in mysterious ways." But what played over and over in Junior's mind, he said, were Father's words that "Often, we are God's instruments!"

All the kids at St. Joseph's heard the same kind of "reminders" from both priests and nuns, but none of us really gave much thought to such ideas, probably because we didn't completely understand half of what we learned by rote and spouted back in class. Even those religious texts we did understand we seldom, if ever, considered applying to our own lives. They were simply religious mantras we needed to know, part of a holy, mental mix stirred in with all the other points of faith that were so glibly imparted to us by the priests and nuns. We were kids; we had other concerns.

But, in the short walk from our house to the rectory, Junior had been able, not only to sort out the idea, but also to understand its personal implications. He had been enraptured, he said, just like the saints they had read about in religion class. Buoyed by a burst of faith and a newfound confidence he never dreamed he had, Junior said he truly believed at that moment that he was "God's instrument" and, as such, had a most holy obligation to rid our household of the demon within it and to "deliver us from evil!" 
But by the time Junior had retraced his steps down the block, day had broken over the still sleeping houses, and a whisper of honeysuckle hung on the early morning air. All the ugly thoughts he had had now receded with the night and with all the other things that live only in the dark.

Grandma responded to Daddy's behavior on a different level than the rest of us did, even when he was at his most violent. Whereas we feared his physical abuse, Grandma wasn't so much afraid of him-after all, she was his mother, if that meant anything-as she was for him, spiritually. But even though she was concerned for his immortal soul, she was also terrorized by his violence and cringed with the rest of us when he went on one of his rampages.

Grandma Louisa tried to shield us from his violence as best she could, and she constantly prayed, mostly aloud, for the salvation of our daddy's soul. Her praying, though, sometimes got on Mama's nerves. In a voice filled with anger and intending to hurt, Mama told her, "Miss Louisa, your son is the devil incarnate! He doesn't have a damn soul!" Still Grandma muttered her prayers, begged Daddy to stop his violence, and pleaded with Mama to "leave him be, for the sake of peace."

"Helen," she begged Mama at various times, "don't sass him, child, please...just ignore him...try not to antagonize him...." What really set Mama on edge was when Grandma suggested "just give him what he wants, baby...."

"Dammit, Miss Louisa!" began Mama's usual electrified response. "You can afford to be generous! You don't have to take his damned abuse! I do!" Then Mama would look away and shake her head in bewilderment. She knew the old lady was as desperate as she was, but Mama would give no ground.

"I will never, as long as I have life and breath, understand how you can expect me to take his shit and then...! Oh, never mind.... That no-good son of a bitch might kick my ass, but I'll be damned if I'm gonna kiss his!"

Grandma seemed at a loss in the face of Mama's blasphemous explosions. Her daughter-in-law had only recently started cussing like that, and each time it shocked Grandma to hear it. "Helen," she whispered, "please! The children..." then muttered something about "stubborn women." But nothing changed. Daddy continued 
to cuss, Mama continued to cuss back, and Grandma continued to pray and beg them both to stop, for the children's sake. We children continued to cower in corners.

One small bit of irony is that Mama learned how to cuss from Daddy. At first she'd simply toss out a word here and there in no particular combination or order, as if she were testing them for effect. Then she learned that there was method, even to the madness of cussing. Eventually, she was able to string the right words together, to really cuss. And when she got good at it, she gave Daddy as good as she got. It was a long time, though, before she reached that point and, even then, she did her cussing on the run, grabbing up children as she went. Usually Daddy didn't follow us any farther than the door, but those times when Mama didn't take the initiative to flight, he would whip out his trusty old pocket knife and chase us all out of the house, anyway-wife, mother, and children. My daddy was an equal opportunity drunk.

Grandma Louisa prayed, as was her habit, even as she crouched with the rest of us in a dark corner of the backyard. "Heavenly Father," she'd whisper, "I know You're going to take him sometime, and when You do, I ask only that You please give him time to say to You, 'Lord have mercy on my soul!'”

When things got really rough, her prayer was only a shake of her yellow-white head and a simple, "Take him, Lord. Please! Take him now." 